\title{
Formation of defused stress areas in the Earth's crust of the Kola region and associated environmental risks in capital construction
}

\author{
VT Filatova $^{1}$ \\ 1 Geological Institute of the Kola Science Centre of the Russian Academy of Sciences (Murmansk Region, Apatity, Russian Federation) \\ Corresponding author: Valentina Filatova (filatova@geoksc.apatity.ru)
}

Academic editor: Aleksandr I. Malov • Received 11 September 2018 Accepted 15 February 2019 Published 12 April 2019

Citation: Filatova VT (2019) Formation of defused stress areas in the Earth's crust of the Kola region and associated environmental risks in capital construction. Arctic Environmental Research 19(1): 20-34. https://doi.org/10.3897/issn2541-8416.2019.19.1.20

\begin{abstract}
This work has been carried out using methods of numerical modeling to detect weakened zones in the basement of the region in regard to the construction and economic human activities. For this purpose, we have constructed quantitative models of the stressed-deformed state of the Earth's crust in the region considering its evolution. Determined for the first time are the structures that accumulated a tectonic-magmatic activity and produced mobile-permeable zones in the Precambrian mainly. For the first time, we have found an interrelation between localities of deep fractures (activation areas) and the stressed-deformed state of the Earth's crust caused by the impact of regional tangential stresses. Most of mineral deposits are located within the identified weakened zones of the geological basement. Economic activity of the population is concentrated there, which affects the ecological situation in the region. In addition, most of the territory where the mobile-permeable areas are detected in the basement is overlapped by known seismogenic zones of the region. Consequently, seismic events with an increased level of magnitude are more often generated in these areas due to the detente of interblock stresses in the geological environment. The provided research indicates the necessity of studying the general geological structure of the region and identifying setting areas of ancient deep deformation structures in design and construction of the major industrial, road, hydraulic engineering and other objects.
\end{abstract}

\section{Keywords}

construction and economic human activities, geological basement, geoecological safety, mobile-permeable areas, Murmansk region, numerical modeling, stress fields, seismicity.

Copyright Filatova VT. This is an open access article distributed under the terms of the Creative Commons Attribution License (CC-BY 4.0), which permits unre. stricted use, distribution, and reproduction in any medium, provided the original author and source are credited. 


\section{Introduction}

The Early Precambrian crust of the north-eastern part Baltic Shield formed during a long geological period, and the observed structure reflects the cumulative effect of multiple transformations. As a result, the geological basement of the region acquired lateral and mosaic heterogeneity. The Murmansk region contains great sources of the most important types of mineral raw materials that predetermined the creation of a powerful mining complex. Currently, more than 100 mineral deposits in the region have a high investment and industrial value. At present, projects for the construction of underground nuclear low-power plants are developed. They can be alternative sources of electric and thermal energy for the development of the Russian Arctic regions. Ensuring safe operating of the underground complex under challenging mining and geological conditions depends significantly on the physical state of the surrounding rock mass as the main protective barrier. At each step of designing and constructing industrial, power engineering (especially nuclear power plants), hydraulic engineering, road and other facilities, it becomes necessary to study the general geological structure of the basement in the region and obtain physical-geological estimates of its strength properties. Solving these tasks in mining areas, which location mostly correlates with the areas of long-lived deep faults, is particularly topical.

Different alternative geotectonic and geodynamic models for the development of the northeastern part of the Baltic Shield are suggested and elaborated (Barbey et al. 1984; Berthelsen and Marker 1984; Melezhik and Sturt 1994; Mints et al. 1996; Balagansky 2002), but up to the present time the processes that led to the specific structure and composition of the ancient crust remain unclear. Interpreting the conditions that cause tectonic deformations is a most essential part of reconstructing the geodynamic regimes predetermining features of the regional development and affecting its metallogenic specialization. One of the most essential features of the tectonosphere is the stress and strain state that controls tectonic and geodynamic processes in the crust. This work was carried out using methods of numerical modeling to explain the dynamic features of the formation of the magmatic structure system in the northeastern part of the Baltic Shield in the period of $3.0-1.6 \mathrm{Ga}$. With this in mind, we constructed quantitative models of the stressed deformed state of the Earth's crust in the region taking into account its evolutionary development. For the first time, we determined the structures that facilitate the ascent of mantle basic-ultrabasic magmas.

We assume that the study region represented a nonuniform elastic body subjected to the action of volume forces and specific stresses at its boundaries. The problem of stresses was solved. The search for weak zones in the basement, which predetermined the localization of magmatic processes, was performed by estimating the maximum shear stresses. For the first time, we found an interrelation of the localization of deep fractures (activation regions) and the stressed deformed state of the Earth's crust caused by the action of regional tangential stresses. Our results allow us to understand the causes of inheritance of the geodynamic activity regions in the Early Precambrian and give grounds to revise the existing concepts about the mechanism of the formation of the Earth's crust in the northeastern part of the Baltic Shield.

According to the map data on the general seismic zoning of Russia (OSR-97-S), the Kola region is characterized by weak seismicity, but from time to time there are earthquakes when the earth's surface vibrates with an intensity of 7 points and above. Such values of vibration intensity can be critical for a number of potentially hazardous industrial facilities caught in the epicenter of earthquakes. Comparison of the localization schemes of the selected mobile-permeable zones in the basement (which are areas of tectonic stress concentration) and known seismogenic zones of the region indicates that they overlap over a larger area, especially at nodal points. Thus, in areas of overlap, the probability of imbalance in the geological environment due to the detente of stresses will be the greatest, and, as a result, seismic risks increase and the vulnerability of civilian and industrial facilities grow stronger, especially underground facilities for various purposes. 


\section{Materials and methods}

\section{Geological features of the region}

The northeastern part of the Baltic Shield is characterized by a long and complex history of development, and the observed structure reflects the cumulative effect of multiple transformations (Zagorodnyi and Radchenko 1983; Petrov et al. 1986; Radchenko et al. 1992; Mitrofanov et al. 1995; Petrov 1999). A significant part of the study region is composed of Precambrian rocks (Radchenko et al. 1992; Mitrofanov et al. 1995). These rocks, whose age is $3.2-2.65 \mathrm{Ga}$ (Kroner and Compston 1990; Bayanova et al. 2002), form the Murmansk, Kola, Belomorian, and Karelian Archaean megablocks, which all together make up a collage structure of the Earth's crust in the region (Fig. 1). The Archaean Keivy structure embedded in

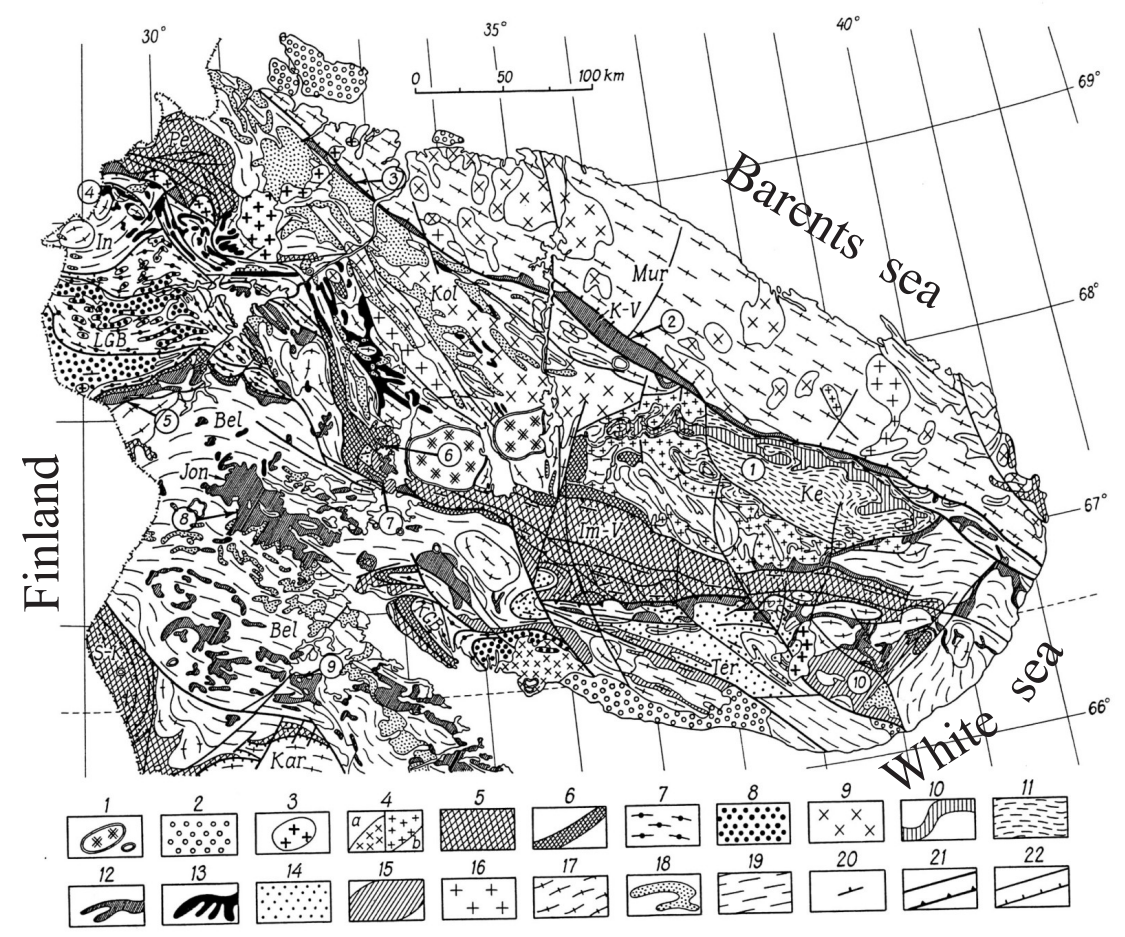

Fig. 1. Geological structural map of the Kola region of the Baltic Shield (from Mitrofanov et al. 1995). Domains: Mur Murmansk, Kol - Kola, Bel - Belomorian, Ter - Tersky, Ke - Keivy, In - Inary. Belts: Jon - Yona, K-V - Kolmozero-Voronja (Archean greenstone belts); LGB - Lapland, KGB - Kandalaksha-Kolvitsa (granulate belts); Pe - Pechenga, Im-V - Imandra-Varzuga, $S$ - $K$ - North-Karelian (Early Proterozoic rocks); (1) contours of Paleozoic intrusions (a-nepheline syenite, b-ultramafic alkaline rocks); (2) Upper Proterozoic sedimentary rocks. Early Proterozoic: (3) granite, granodiorite and diorite; (4) charnokite and granite (a), alkalinegranite (b); (5) volcanic-sedimentary rocks; (6) anorthosite and gabbro-anorthosite (in Keivy - Archean), gabbro, pyroxenite, peridotite. Early Proterozoic (or Archean?): (7) basic and intermediate granulite; (8) acid granulite. Late Archean: (9) granodiorite, diorite and enderbite; (10) alumina and super-alumina gneiss and schist; (11) acid gneiss; (12) fragments of greenstone belts (gneiss, amphibolites and komatiite); (13) fragments of banded iron formation (gneiss, amphibolites and ferruginous quartzite); (14) gneiss and schist; (15) gneiss and amphibolites; (16) granodiorite and diorite; (17) plagiogranite and granite-gneiss; (18) kyanite-garnet-biotite gneiss; (19) granite-gneiss, gneiss, migmatites and, rarely, amphibolites. (20) strike and dip; (21) subvertical faults and gentry dipping thrusts that separate the Proterozoic domains; (22) subvertical faults and thrusts. Encircled numbers indicate type-sections: 1 - Keivy, 2 - Kolmozero, 3 - Ura-Guba, 4 - Kaskama, 5 - Korva, 6 - Ar-Varench, 7 - Voche-Lambina, 8 - Iona, 9 - Kovdozero, 10 - Tersky 
the structure of the Kola megablock is distinguished among the secondary structures owing to the peculiarities of its structure (Mitrofanov et al. 1995). In addition, the following structural zones are significant: the Archaean greenstone belts, i.e., Kolmozero Voronje, Yona, and Tersky- Allarechka, and the Early Proterozoic mobile belts, i.e., the Lapland granulate belt and Pechenga - Varguza rift belt, as well as the giant Paleozoic alkaline intrusions (Khibiny, Lovozero). The Early Proterozoic Pechenga - Varguza rift belt inherits the development region of the Archean Tersky - Allarechka belt. The Upper Archaean - Early Proterozoic period is characterized by linear tectonics and formation of belt structures, which were zones of repeated manifestation of mafic magmatism. All belt structures are divided by vast fields of infra - supracrustal, deep metamorphic sialic complexes. Magmatic formations including those of mafic - ultramafic composition play an important role in the development and formation of the crust in the region. The major part of the presently known mafic - ultramafic intrusions reveals spatial correlation with the zones of deep persistent fractures and rift genesis.

\section{Natural and induced seismicity of the region}

Regular seismological observations on the territory of the Murmansk region have been carried out since 1956 (Panasenko 1969). In general, the region belongs to areas of weak seismicity, but earthquakes occur relatively seldom, which can cause the surface damage, such as ruptures and landslides. The greatest number of seismic events both ancient and modern occurred in the Murmansk and Kandalaksha regions, where, along with weak earthquakes, there were also seven-point earthquakes. In the process of studying various types of deformations in the Quaternary sediments of the valley of the Pechenga River (the western part of the Murmansk block), traces of strong ancient earthquakes were noted, which were observed both in loose sediments and in crystalline rocks (Nikolaeva 2006). It also shows that in the range of 8.5-8.7 thousand years ago there was a manifestation of a strong seismic pulse with magnitude of 7.1 and above. Ear- lier it was noted that this area was already exposed to earthquakes about $8950 \pm 150$ years ago (Mitrofanov et al. 1995). In addition, seismic events occurring in the western part of the Murmansk block in 1772 and 1819 with a magnitude of 4.6 and 4.1 are described, respectively (Ahjos and Uski 1992). As appears from historical records, an earthquake was observed in the Kandalaksha area on May 14, 1626; the earthquake magnitude varied from 5.1 to 6.5 and the ground vibration magnitude was up to 7.5 (Stepanov 2001). In the modern age (the period of instrumental observations: February 2, 1960) a series of events with $M$ > 4 , which induced ground vibration with a magnitude higher than 5 was registered (Panasenko 1969).

Figure 2 shows the disposition of the seismogenic zones of the Kola Peninsula, identified by the authors (Baranov et al. 2011) for the period of 9-13 thousand years ago. The most reconstructed paleoseismic dislocations are in the selected zones. The presented scheme is based on the results of a long-term research conducted in the northeastern part of the Baltic Shield in order to carry out reconstructions of paleoseismic dislocations (Nikolaeva 2001, 2002, 2006). The zones have a linear view with intersection nodes, stretching from the north-west to the south-east

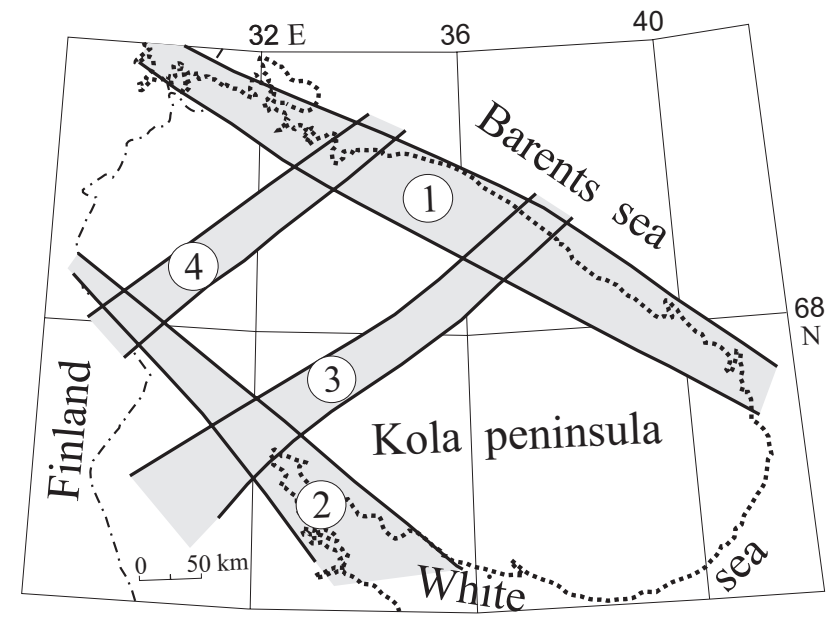

Fig. 2. Ancient seismogenic zones of the Kola Peninsula according to paleoreconstructions for a period of 9-13 thousand years ago (from Baranov et al. 2011). Numerals in circles indicate zones: 1 - Murmansk; 2 - Kandalaksha; 3 - Khibiny-Kharlovka; 4 - Tuloma 
(Murmansk and Kandalaksha), and from the southwest to the northeast (Tuloma and Khibiny-Kharlovka). Directly paleoseismic dislocations tend to appear in zones of long-living deep faults and in areas where crust breaks, shifts and subsidence of blocks are observed both in crystalline rocks and in sedimentary ones. The uplift of the region's crust and intraplate vertical displacements of individual blocks with different speeds occurred during the deglaciation period (9-13 thousand years ago), and the resulting detente of interblock stresses caused earthquakes (Nikolaeva and Yevzerov 2018). Currently the uplift of the shield is still ongoing and as for tectonic regime, the role of vertical motions is waning. In this case, horizontal compressive stresses come to the first place, the detente of which also gives rise to seismic events.

Figure 3 shows the location of seismogenic zones based on the seismic monitoring data over the period of 1956-1993 (Vinogradov et al. 2016). The scheme (Fig.3) includes 6 zones distinguished by the results of seismic monitoring ( 1 - Murmansk; 2 - Kandalaksha; 3 - Khibiny-Lovozero; 4 - Kuusamo-Poria Guba; 5 Belomorie; 6 - Botni-Finnmark). Epicenters of earth-

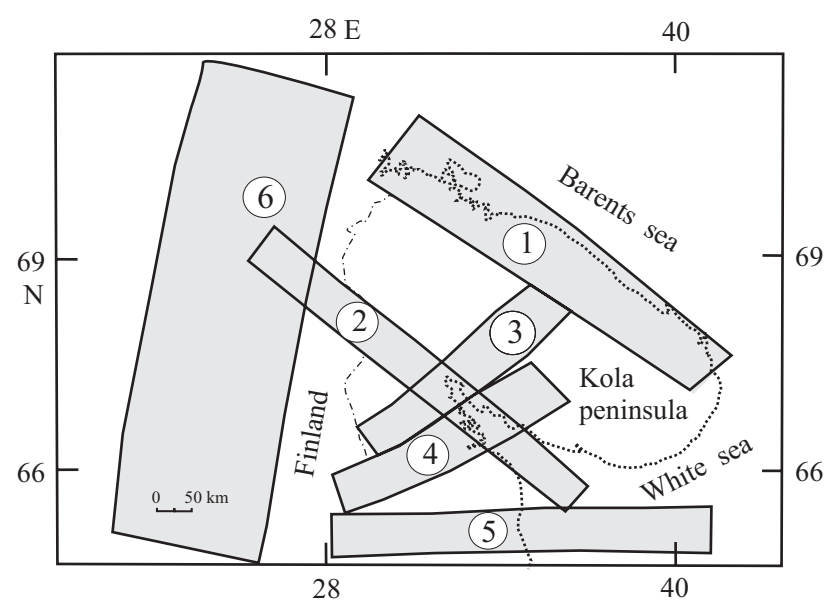

Fig. 3. Seismogenic zones according to the regional monitoring network data in 1956-1995 in the Kola Peninsula (from Vinogradov et al. 2016). Numerals in circles indicate zones: 1 - Murmansk ; 2 - Kandalaksha; 3 - Khibiny-Lovozero; 4 - Kuusamo-Poria Guba; 5 - Belomorie; 6 - Botni-Finnmark quakes for that period were predominantly recorded within these zones. It should be noted that in the first ten years of instrumental measurements, increased seismicity was recorded in the Murmansk and Kondalaksha zones, but after 1966 an increase in seismicity was observed in the Khibiny-Lavozero, Kuusamo- Poria Guba and Botni-Finnmark zones. If we consider the time interval from the beginning of the region's seismic monitoring, since 1956, the Kandalaksha zone is the most seismically active region of the Kola Peninsula. Until 1969 only the Khibiny massif area was reliably distinguished by seismic activity within the limits of the Khibiny-Lovozero zone which has become a belt of increased seismic activity only for the period 1970-1990.

The decrease in the earthquake frequency was recorded in the range of 1993-2013, but the shape of seismogenic zones also changed (Vinogradov et al. 2016). It should be noted that during this period the reconstruction of the network of seismic observations began: the analog seismic stations were replaced with the digital ones, and additional stations were installed. New opportunities for the separation of natural and induced seismic events have appeared.

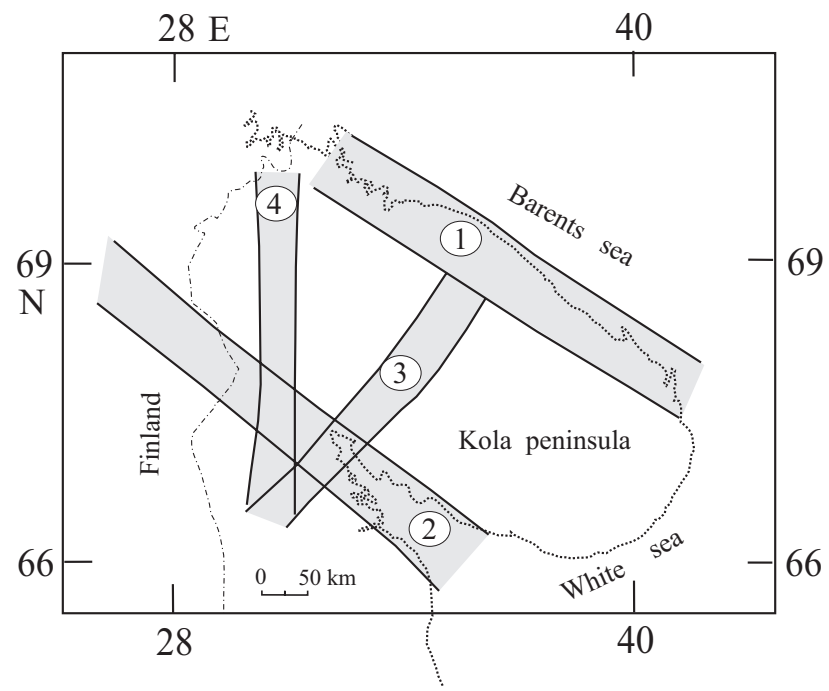

Fig. 4. Seismic zones location according to the regional seismic monitoring data in 1993-2013 in the Kola Peninsula (from Vinogradov et al. 2016). Numerals in circles indicate zones: 1 - Murmansk; 2 - Kandalaksha; 3 - Khibiny-Lovozero; 4 - Kandalaksha-Varenga 
Therefore, the number of reliably established natural earthquakes has decreased. Figure 4 shows the seismogenic zones disposition for the specified period. It is noted that the seismicity in the Murmansk zone has noticeably decreased, but in the zones Kandalaksha and Khibino-Lavozero remained at the same level (Vinogradov et al. 2016). At the same time, the Kuusamo- Poria Guba zone disappeared, but the Kandalaksha-Varenga zone appeared. Thus, the spatial evolution of the selected zones is observed, within which the largest number of seismic events were recorded for one or another period of time. In addition, the authors of the work (Vinogradov et al. 2016) concluded that, in general, in the region there is an increase in seismicity.

The results of seismic monitoring show that the activity of seismogenic zones is not constant and there is no sinchronicity in its manifestation in different zones (Fig. 3,4). An increase in seismicity can be observed in some areas, while in others, attenuation. In addition, over time, new seismogenic zones may appear, exciting territories where no seismic activity had previously been observed. The observed variations of the seismic activity of the region allow us to distinguish two periodicities in its spatial structure: 2-3-year-old and 8-9-year-old, which overlap each other (Vinogradov et al. 2016). Therefore, it can be assumed that in 2019-2020 there will be an increase in the number of recorded natural earthquakes in the Murmansk region.

In addition to tectonic earthquakes, induced seismic events occur due to the disturbance of the natural equilibrium in massifs, which occurs because of the active development of the region's mining and industrial complex on the Kola Peninsula. A tectonic rockburst occurs directly in the mine working, in which the magnitude level is higher than that of an induced earthquake, the center of the latter is located in the massif outside the working area. Because of this, tectonic rockbursts cause much greater damage than induced earthquakes. The largest induced earthquake in the region with a magnitude of $\mathrm{M}=4.0$ was recorded in 1999, which caused the destruction of the underground workings of the Umbozero mine (the Lovozero massif) over an area of $650 \mathrm{~km}^{2}$ with the development of a crack to a surface $0.5 \mathrm{~km}$ long (Lovchikov 2013).

Previously, seismic events were never recorded in the Lovozero massif, but in the 90s earthquakes with a magnitude of $M>1$ began to occur and their number increased annually. Moreover, a relationship is established between the emergence and increase of induced seismic activity of the Lovozero massif with the commissioning and increase in production at the Umbozero mine (Lovchikov 2013). Due to the change in the stress state of massif, a series of rockburst with a magnitude of $\mathrm{M}=2.2-2.6$ followed. Further continuation of the mining operations led to the relaxation of the potential energy in the massif, which caused a tectonic rockburst with a magnitude of $M=5.1$ (local scale of the Richter magnitude) in 1999 (Lovchikov 2013). When exploitation of the mine was stopped the number of seismic phenomena within the massif has decreased markedly in recent years. In addition to the Umbozero mine, strong seismic events (rockburst and induced earthquakes) also occurred at the Kirovsk mine in the Khibiny, but the energy level of these events was lower.

\section{Statement of the problem and principal equations}

In the Late Archaean, consolidation of the Earth's crust transformed the region into a relatively stable continental structure, and by that time, the study region was in a stable state (Bel'kov 1987). Hence, we can admit that the region could have been subjected to overall uniform compression owing to remote forcing. In the Early Proterozoic, the main front of tangential stresses was directed to the northeast (Zagorodnyi and Radchenko 1983; Radchenko et al. 1992). The Murmansk megablock was in a stable position. It is not improbable that it was subjected to stress directed from northeast to southwest. Hence, we admit that, in the Early Proterozoic, the region was subjected to monoaxial compression by uniformly distributed forces from the southwest and northeast.

We assume that the northeastern part of the Baltic Shield over the entire period of the geological history of the region represented an inhomogeneous 
elastic body subjected to the impact of volume forces and specific stresses at its boundaries (Filatova 2014). We also admit that (a) the tectonic magmatic activity established in the Early Precambrian was of the intraplate type; (b) the configuration of contact boundaries between the Archaean megablocks did not change strongly over the entire geological history. The region considered here consists of a few finite subregions. Each of them is considered uniformly isotropic and linearly elastic with linear elastic constants (Poisson coefficient $\mu$ and Young modulus E). Each Archaean megablock is a separate subregion. The zones of deep fractures dividing the Archaean megablocks are considered as subregions with a width of $15-30 \mathrm{~km}$. We specify the condition that the region is in the equilibrium state and the components of the stress tensor $\sigma_{i j}$ in the case of the plane problem satisfy the equilibrium conditions (Muskhelishvili 1966):

$$
\frac{\partial \sigma_{x x}}{\partial x}+\frac{\partial \sigma_{y x}}{\partial y}+\beta_{x}=0, \frac{\partial \sigma_{x y}}{\partial x}+\frac{\partial \sigma_{y y}}{\partial y}+\beta_{y}=0 .
$$

where $\beta_{x}$ and $\beta_{y}$ are volume forces. We used the method of boundary elements to numerically solve this boundary problem with respect to stresses. The numerical solution is constructed using previously obtained analytical solutions for simple singular problems so as to satisfy the specified boundary conditions at each element of the contour (Crouch and Starfield 1983). We consider the upper horizontal surface of the solid medium model.

Three time stages of the Kola region development were considered in the course of solving the formulated problem $(3.0-2.8,2.8-2.5,2.5-1.6 \mathrm{Ga})$, and correspondingly, a certain basic model was specified at each of the stages that describes the study region with account for the geological structures formed by the corresponding time (Filatova 2014) (Fig. 5). With this in mind, we defined a rectangular contour for simulations that envelope the study region including the Murmansk, Kola, and Belomorian megablocks and the marginal region of the Karelian megablock in the contact zone with the Belomorian megablock. The area of the specified contour significantly exceeds the study region in order to exclude the influence of the contour boundaries in the simulations. Stress $T$ was specified along the entire boundary in the numerical experiment. Since we do not have reliable data on the absolute value of forces in the region, we assume that their intensity $T$ is equal to unity and obtain stresses in the simulations in the units of T. Stresses $\sigma_{x x}$, $\sigma_{y y}, \tau_{x y}$ were estimated for each basic model, which alloywed us to calculate the main stresses $\bar{\sigma}_{x x}, \bar{\sigma}_{y y}, \bar{\tau}_{x y}$ and the maximum absolute values of shear stresses (Muskhelishvili 1966):

$$
\left|\tau_{x y}\right|_{\max }=\left|\frac{\bar{\sigma}_{x x}-\bar{\sigma}_{y y}}{2}\right| .
$$

The main stresses were calculated using the following relations (Muskhelishvili 1966):

$$
\begin{aligned}
& \bar{\sigma}_{x x}=\frac{\sigma_{x x}+\sigma_{y y}}{2}+\frac{\sigma_{x x}-\sigma_{y y}}{2} \cos 2 \alpha+\tau_{x y} \sin 2 \alpha, \\
& \bar{\sigma}_{y y}=\frac{\sigma_{x x}+\sigma_{y y}}{2}-\frac{\sigma_{x x}-\sigma_{y y}}{2} \cos 2 \alpha-\tau_{x y} \sin 2 \alpha, \\
& \bar{\tau}_{x y}=-\frac{\sigma_{x x} \sigma_{y y}}{2} \sin 2 \alpha+\tau_{x y} \cos 2 \alpha,
\end{aligned}
$$

where $\alpha$ is the angle between the axis of the main stress with the $O X$-axis, $\operatorname{tg} 2 \alpha=2 \tau_{x y} /\left(\sigma_{x y}-\sigma_{x y}\right)$.

Finally, the values of stresses $\left|\tau_{x y}\right|_{\text {max }}$ were normalized and presented as percentage of the maximum value over the region. Thus, after normalizing, the domains with anomalous shear stresses were considered as weak zones in the basement of the region. All the works were carried out using a scale of $1: 1000$ 000 and the initial geological chart of the region with a scale of 1:500000 (Mitrofanov 1996). Simulations for several versions of the load applied to the region were performed. In the case of overall uniform compression of the region (Fig. 5a, 5b) and mono-axial compression along the southwest-northeast line (Fig. $5 \mathrm{c}$ ), the structural peculiarities of the region caused by the development of the permeable zones of the Earth's crust were pronounced most clearly.

The values of linear elastic constants $(\mu, E)$ for the rocks of the Archaean megablocks, greenstone belts, Keivy structure, and fracture zones were specified according to the data presented in (Filatova 2009). The 

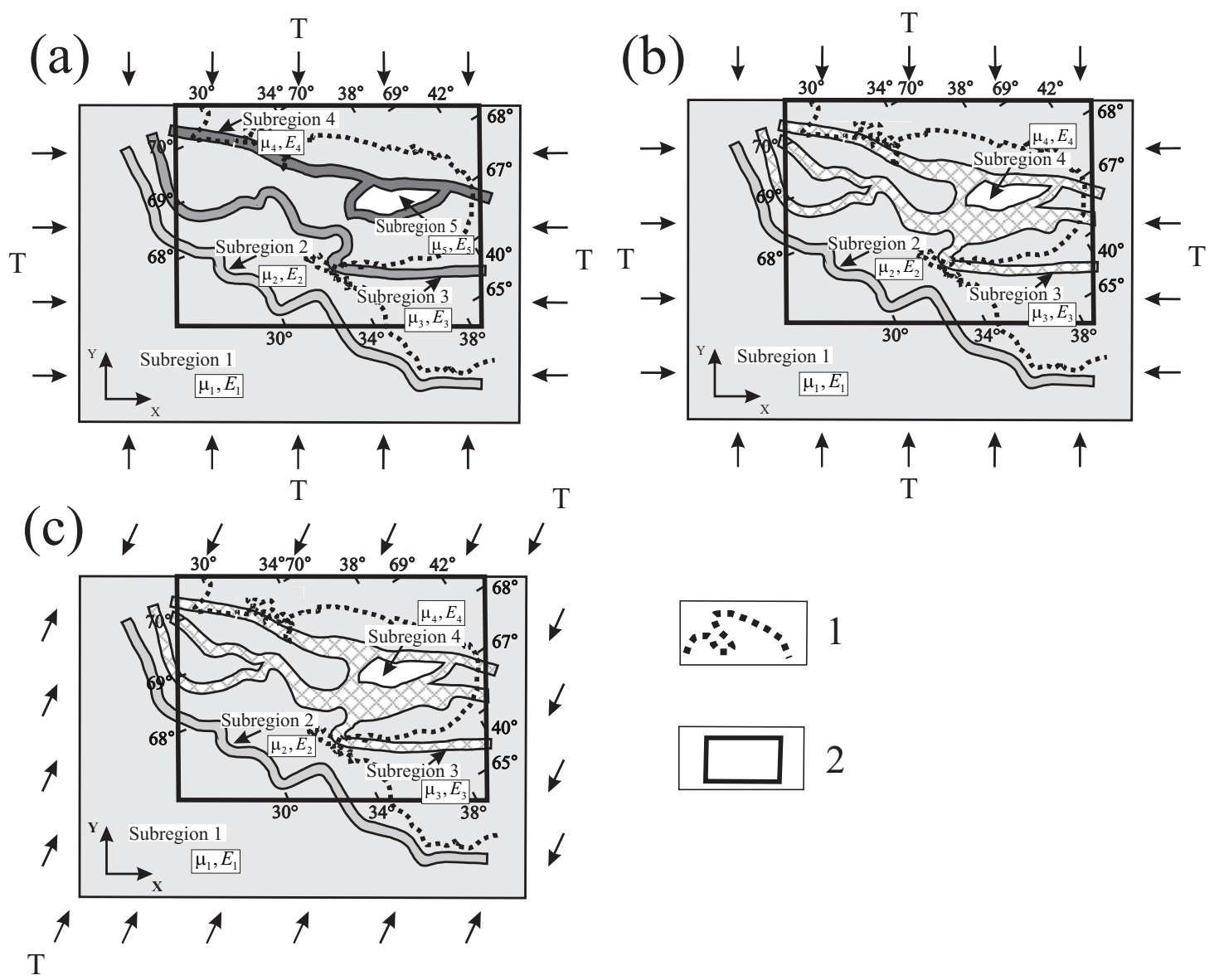

Fig. 5. Model block regions: approximation schemes of the Earth's crust block structure in the northeastern part of the Baltic Shield for the period of 3.0-1.6 Ga (from Filatova 2014). (a) 3.0-2.8 Ga; (b) 2.8-2.5 Ga; (c) 2.5-1.6 Ga; (1) contours of the modern coastline; (2) contours of the study region; $T$ is force

Poisson coefficient in the simulations for the Archaean megablocks (Karelian, Murmansk, Kola, and Belomorian) and the Keivy structure was assumed equal to $\mu=0.25$, while in the weak zones it was $\mu=0.3$. The zones of deep fractures dividing the Archaean megablocks were considered weak. The Young modulus in each of the subregions was determined as the weighted mean value: in the Karelian, Murmansk, Kola, and Belomorian megablocks, it was taken equal to $E=$ $6.2 \cdot 10^{4} \mathrm{MPa}$, and in the Keivy structure it was $E=$ $5.8 \cdot 10^{4} \mathrm{MPa}$. In the weak (fracture) zones, the Young modulus was taken as one order of magnitude smaller. The regions of the Kolmozero-Voronja and Tersky - Allarechka greenstone belts, respectively, and the
Pechenga - Varzuga rift belt, may be considered as weak zones because they represent mobile permeable structures.

\section{Basic model: age interval of 3.0-2.8 Ga}

The basic model includes structural elements of the Archaean basement formed by the moment of termination of the Earth's crust accretion in the region. The following structures are considered as subregions: the Murmansk, Kola, Belomorian, and Karelian megablocks, the Keivy structure, and also the fracture zones dividing the megablocks (Fig. 5a). The region is 
subject to overall uniform compression. The boundary conditions at the contour enveloping the study region were specified conventionally: $b_{s}^{i}=\left(\sigma_{s}^{i}\right)_{0}$ and $b_{n}^{i}$ $=\left(\sigma_{n}^{i}\right)$. We assume that the region at its boundary is subject to equal normal stress $\left(\sigma_{n}^{i}\right)_{0}=T$, and the tangential stress is $\left(\sigma_{s}^{2}\right)_{0}=0$. At the contact surface between subregions $r_{1}$ and $r_{2}$, at each of its points $q$, we specified the conditions of continuous force

$$
\sigma_{s}^{r_{1}}(q)=\sigma_{s}^{r_{2}}(q) \text { and } \sigma_{n}^{r_{1}}(q)=\sigma_{n}^{r_{2}}(q) \text {. }
$$

\section{Basic model: age interval of $2.8-2.5 \mathrm{Ga}$}

The initial basic model is supplemented with the subregions marked by anomalous values of shear stresses at the first stage of investigation; they overlap the development territories of the Kolmozero-Voronja and Tersky-Allarechka greenstone belts (Fig. 5b). The region is also subject to overall uniform compression. The boundary conditions at the contour of the study region were specified in a manner similar to the first basic model (Fig. 5a). The conditions of continuous force were also specified at the contact surface between the subregions.

\section{Basic model: age interval of $2.5-1.6 \mathrm{Ga}$}

The configuration of the subregions in the initial basic model to a great extent resembles the second model (Fig. 5c). The region is subject to mono-axial compression by uniformly distributed force $T$ from the southwest and northeast. The directions of compression were selected according to the direction of the gaping fault of the Pechenga-Varzuga rift system and with the direction of the general front of tectonic stresses in the region. If we take the condition that the $Y$-axis in the local coordinate system coincides with the direction of compression, we get

$\left(\sigma_{x x}^{\prime}\right)_{0}=0,\left(\sigma_{y y}^{\prime}\right)_{0}=T,\left(\tau_{x y}^{\prime}\right)_{0}=0$

Let us make a transition to the unique coordinate system for all models and perform rotation of the coordinate axes by angle (Muskhelishvili 1966): $\left(\sigma_{x x}^{i}\right)_{0}=\left(\sigma_{x x}^{\prime}\right)_{0} \cos ^{2} \beta+2.0 \cdot\left(\tau_{x y}^{\prime}\right)_{0} \sin \beta \cos \beta+\left(\sigma_{y v}^{\prime}\right)_{0} \sin \beta$, $\left(\sigma_{y y}^{i}\right)_{0}=\left(\sigma_{x x}^{\prime}\right)_{0} \sin ^{2} \beta-2.0 \cdot\left(\tau_{x y}^{\prime}\right)_{0} \sin \beta \cos \beta+\left(\sigma_{y y}^{\prime}\right)_{0} \cos ^{2} \beta$, $\left(\tau_{x y}^{i}\right)_{0}=\left(\left(\sigma_{y y}^{\prime}\right)_{0}-\left(\sigma_{x x}^{\prime}\right)_{0}\right) \sin \beta \cos \beta+\left(\tau_{x y}^{\prime}\right)_{0}\left(\cos ^{2} \beta-\sin ^{2} \beta\right)$.

We eventually get the boundary conditions along the contour of the region in the following form (Muskhelishvili 1966):

$$
\begin{aligned}
& \left(\sigma_{s}^{i}\right)_{0}=\left(\left(\sigma_{y y}^{i}\right)_{0}-\left(\sigma_{x x}^{i}\right)_{0}\right) \sin \beta \cos \beta+\left(\tau_{x y}^{i}\right)_{0}\left(\cos ^{2} \beta-\sin ^{2} \beta\right), \\
& \left(\sigma_{n}^{i}\right)_{0}=\left(\sigma_{x x}^{i}\right)_{0} \sin ^{2} \beta-2\left(\tau_{x y}^{i}\right)_{0} \sin \beta \cos \beta+\left(\sigma_{y y}^{i}\right)_{0} \cos ^{2} \beta .
\end{aligned}
$$

The conditions of continuous forces were maintained at the contact surface between the subregions.

\section{Results}

Figure 6 presents the weak zones in the region distinguished from the anomalous values of maximum shear stresses (Filatova 2014). They formed in the Late Archaean-Early Proterozoic. These regions have a shape of belt structures and correlate with the regions of mafic-ultramafic intrusions distribution and with zones of tectonic distortions in the Kola region. The simulations for the first basic model (Fig. 5a) allowed us to distinguish weak zones 1-7, zones $8-14$ in the second basic model (Fig. 5b), and zones $15-25$ in the third basic model (Fig. 5 c). The distinguished zones 1-4 (Kolmozeo-Voronja (1), Terskii-Allarechka belt (2), Tsaga (3), and Shchuchieozero (4)) are known from the geological data as the Archaean magma conducting regions. This was confirmed by the results of modeling. Zones 5-6 (Tuloma (5) and Kolvitsa (6)) are known as Early Proterozoic ones. Zone 7 (Liinakhamar) is traced along the fracture of the northeastern direction that crosses the Murmansk and Kola megablocks. The regional geologists consider that the fractures of the northeastern extension are Archaean (Zagorodnyi and Radchenko 1983; Bel'kov 1987). The distinguished zones 8-12 (Mt. Generalskaya (8), Porjitash zone (9), Salny Tundra zone 1 (10), Salny Tundra zone 2 (11), Moncha Tundra zone (12)) are Early Proterozoic. Zone 13 (Khibiny) is known as Paleozoic. 


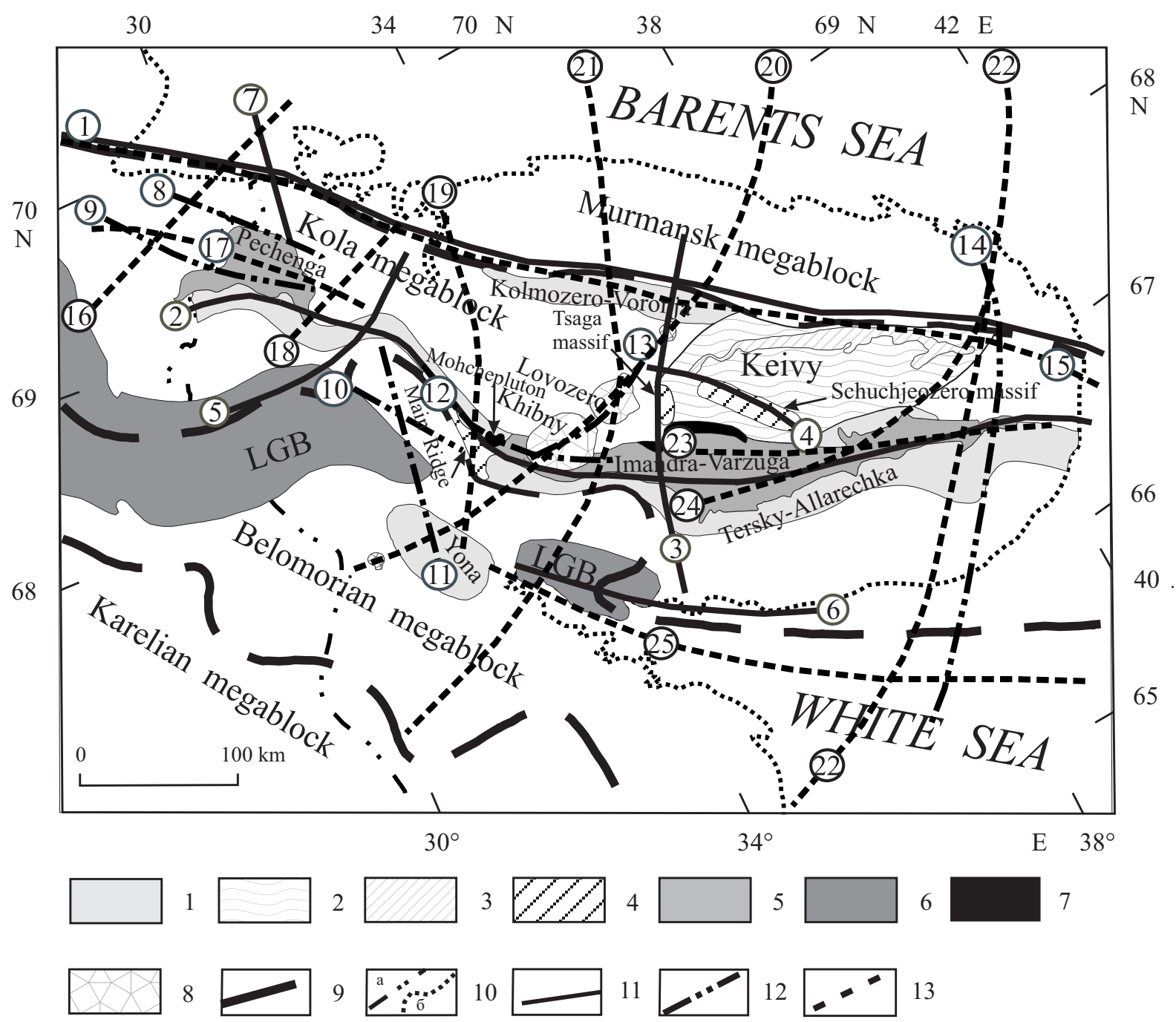

Fig. 6. Weak zones in the Kola region basement formed in the Early Precambrian in the time interval of 3.0-1.6 Ga (from Filatova 2014). (1) Archaean belts: Kolmozero-Voronje, Tersky-Allarechka, and Yona; (2) Keivy structure; (3) Highly alumina gneiss of the Keivy series (polar fox tundra column); (4) Anorthosite intrusions and gabbro-anorthosites (Archaean-Early Proterozoic); (5) Pechenga-Imandra-Varguza paleorift belt; (6) Lapland granulate belt; (7) Layered massifs of basic and ultrabasic rocks (Early Proterozoic); (8) Alkaline intrusions (Paleozoic); (9) Fractures (fracture zones) at the contact between megablocks; (10) (a) State border of Russia, (b) modern coastline. Magma conducting (weak) zones distinguished on the basis of anomalous values of simulated maximum shear stresses: (11) formed in the interval of 3.0-2.8 Ga; (12) in the interval of 2.8-2.5 Ga; (13) in the interval of 2.5-1.6 Ga. Numbers in circles indicate distinguished zones: (1) Kolmozero-Voronja belt; (2) Terskii-Allarechka belt; (3) Tsaga zone; (4) Shchuchieozero zone; (5) Tuloma zone; (6) Kolvitsa zone; (7) Liinakhamar zone; (8) Mt. Generalskaya; (9) Porjitash zone; (10) Salny Tundra zone-1; (11) Salny Tundra zone-2; (12) Moncha Tundra zone; (13) Khibiny zone; (14) East Kola zone; (15) North Kola zone (Kolmozero-Voronja); (16) Vaynospaa zone; (17) Pechenga zone; (18) Litsa-Araguba zone; (19) Kola-Imandra Lake zone; (20) Kontozero-Khibiny-Kovdor zone; (21) Continuation of the western slope of the East Barents Sea rift system; (22) Continuation of the eastern slope of the East Barents Sea rift system; (23) East Keivy-Panarechka zone; (24) Imandra-Varguza zone; (25) Kandalaksha zone 


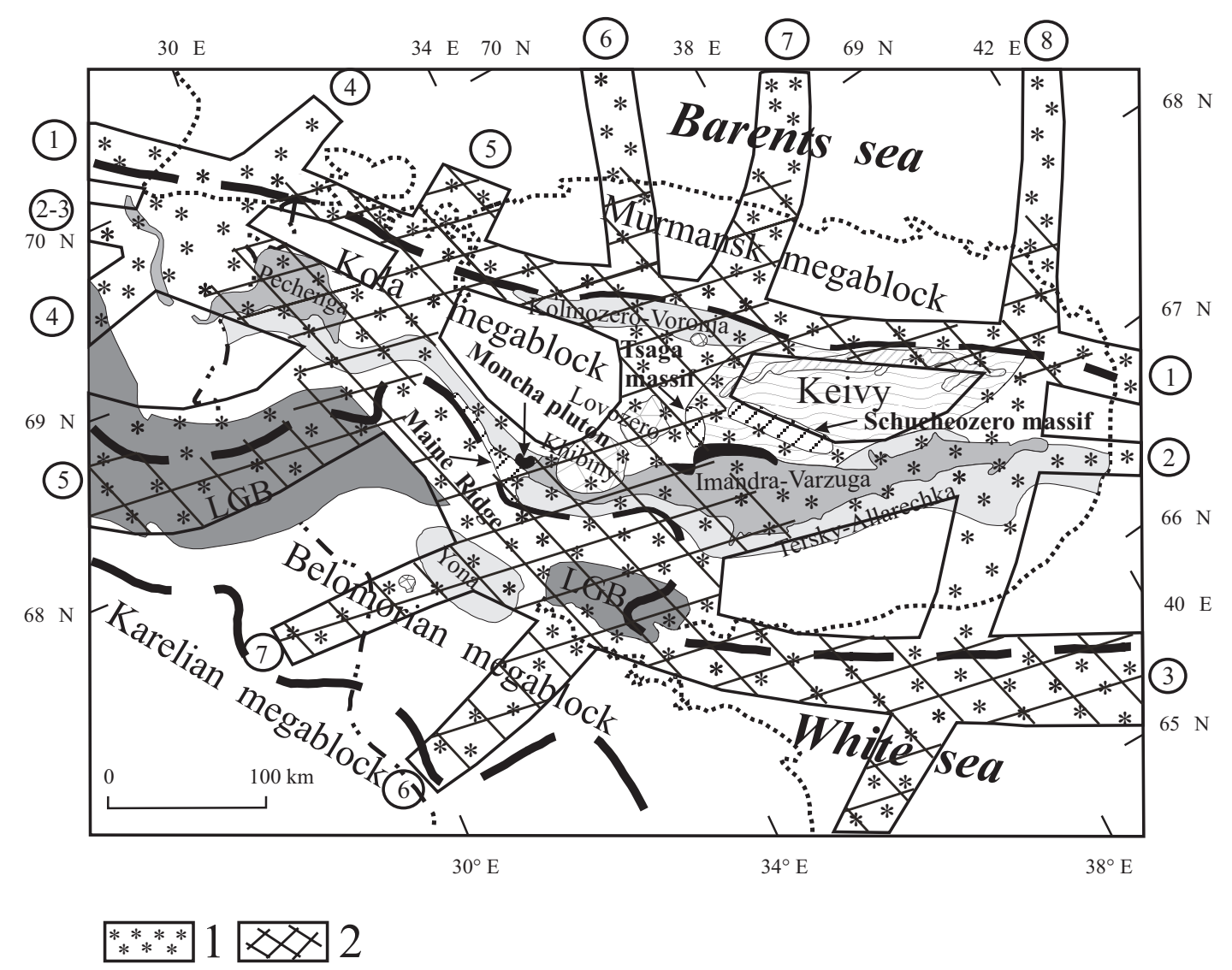

Fig. 7. Scheme of the ancient deformation magmatic structures location (frame tectonogens) in the northeastern part of the Baltic Shield. (1) Area of development zones of increased permeability of the crust; (2) territory of the detected mobile permeable zones, including areas of increased seismicity as ancient (interval 9-13 thousand years ago), and modern (1956-2013). Numerals in circles indicate reconstructed mobile permeable zones in the Archean basement of the region. Symbols are shown in Fig. 6

Zone 14 (East Kola) spreading in the submeridional direction that crosses the eastern part of the Kola Peninsula and the White Sea basin is not considered as a magma conducting structure; its age and genesis are not known. It is worth noting that zone 14 crosses the system of fractures shown in tectonic schemes (Zagorodnyi and Radchenko 1983, Bel'kov 1987, Radchenko et al. 1992) at an angle of $10^{\circ}$. The admitted estimate of the origination time is Late Archaean. Zone 15 (North Kola) is known as Archaean (Kolmozero-Voronja), but magmatic activity was also later observed in this region. Zones 16-19 (Vaynospaa (16), Pechenga (17), Litsa-Araguba (18), and Kola-Imandra Lake (19)) are Early Proterozoic. Zone 20 (Kontozero-Khibiny-Kovgor) is known as Paleozoic. Zones 21 and 22 are continuations of the slopes of the Eastern Barents Sea rift system of Paleozoic age (continuation of the western slope (21), continuation of the eastern slope (22)). Zones 23 and 24 (Eastern Keivy-Panarechka (23), Imandra-Varzuga (24) are of Early Proterozoic age, and zone 25 (Kandalaksha) is known as Riphean.

Identified weak zones in the basement of the Kola region are mostly superimposed and do not change the shape of enclosing megablocks and together form a frame, which unites the main structural el- 
ements (Archean megablocks) of the region (Fig. 7). Fig. 7 shows that the reconstructed ancient mobile permeable structures 1-3 extend from northwest to southeast, structures 4-8 - from the southwest to the northeast. Areas 1, 2, 3, and 5 formed in the Archean as weakened zones, areas $4,6,7$, and 8 - in the early Proterozoic. It should be noted that the central part of structures 6, 7, and 8 (within the Kola megablock) began to form even in the Archean time.

Mobile permeable zones formed in the crust of the region may be considered as frame tectonogens, which according to the terminology suggested by YuM Sheinmann (Sheinmann 1968) represent linear deformation igneous structures. These structures were the regions of stress relaxation in the crust, along which the crust was reconstructing during each of the tectonic cycles so that the crust qualitatively changed. At each stage of the Earth's crust development, the geotectonic contrasts were intensified and, correspondingly, the structure of tectonogens became more complex. Eventually, the ancient Archaean blocks of the region were crossed by a system of frame tectonogens controlling the local energy accumulation, which led to sharp activation of tectonic, thermal, and igneous processes.

Any critical situations in the origination of the ancient crust could have caused formation of deep fractures (activation regions) precisely in the weak zones that control the location of ore belts of sequential metallogenic epochs. Model simulations provide evidence of this viewpoint. These demonstrate that the main magma - releasing structures of the region are characterized by anomalous shear stresses. This is supported by the results of modeling, showing that all the main magma-producing structures of the region are marked by abnormal values of shear stresses, which were caused by the action of regional tangential stresses. The region is currently experiencing horizontal compressive stresses (Mel'nikov 2002; Nikolaeva and Yevzerov 2018). The identified weakened zones in the basement of the region are also areas of tectonic stress concentration. Consequently, in the case of seismic activity, these zones become potentially dangerous during the stress relaxation between geoblocks.

\section{Discussion}

Taking into account the fact that the rise of the shield is still ongoing and there are both vertical and horizontal movements of the structural elements of the crust, therefore, relative geoblock shifts to each other will occur along the weakened zones of the basement - within the frame tectogens. In this case, the stresses arising at the junctions of the blocks during discharge can generate seismicity. The identified paleoseismic deformations are mainly confined to areas of long-lived faults, discontinuities, shifts and vertical movements of blocks (Nikolaeva 2001; Nikolaeva and Yevzerov 2018). An analysis of the layout of the Kola Peninsula ancient seismogenic zones (Fig. 2) shows that they are correlated with the position of the identified weakened areas in the basement of the Kola region - frame tectonogens (zones 1,3,5,7 in Fig. 7). In addition, the similarity is observed when comparing the location of tectonogens and seismogenic zones, constructed according to seismic monitoring data for the period 1956-1993. The correlation is most clearly manifested in the following segments such as: the Murmansk block (especially its western part, the junction zone with the Kola block) - the Murmansk seismogenic zone; the Kandalaksha weakened zone in the basement (especially, the White Sea and Kandalaksha Bay areas) - the Kandalaksha seismogenic zone; the weakened zone Kontozero-Lovozero-Khibiny-Kovdor - the Khibiny-Lovozero seismogenic zone. In addition, there is a practical coincidence of the location of the nodal points of intersection of both the identified weakened zones in the basement of the region, and seismogenic zones. Thus, most of the known seismic events of the region fall within areas of frame tectonogens.

The authors of the work (Kalashnik and Maksimov 2016) performed an analysis of data on seismic events recorded on the Kola Peninsula. At the same time, data on the energy saturation of rock mass in the near-surface part of the earth's crust of the region were taken into account (Mel'nikov 2002).

It was concluded that the probability of an earthquake of magnitude $M=5$ in the Murmansk region over 50 years is statistically getting close to $100 \%$. It 
should be added that the damage caused by an earthquake to engineering facilities depends not only on the magnitude of the seismic event, but also on the depth of its source and the distance to the object in question. In this case, shallow-focus earthquakes with a hypocenter depth of 10-12 km are of particular danger. For example, in case of an earthquake with a magnitude of 5 , the intensity of the earth's surface oscillations will exceed 7-9 on the MSK-64 scale in the epicenter (Vinogradov et al. 2016; Kalashnik and Maksimov 2016). The estimates characterizing the degree of danger for technical objects are given on the example of the main pipeline: destruction of the above-ground pipeline occurs with seismicity of 6-7 points, and the underground pipeline - with 7-8 points (Kalashnik and Maksimov 2016). Taking into account the active development of the mining-industrial complex of the Murmansk region, a possible increase in the number of induced earthquakes and, accordingly, the associated tectonic rockburst cannot be ruled out.

\section{Conclusions}

The results of our research demonstrate that development of tectonogens (mobile permeable zones) is caused not only by the influence of the deep mobile zones whose roots penetrate into the mantle, but also by the stressed deformed state of the Earth's crust subjected to the influence of external tectonic forces. The investigations revealed the heredity of magma feeding channels in the region from the Archaean to the Early Proterozoic, which is confirmed by geological data. The analysis shows that the areas where tectonogens of different ages intersect are characterized by a wider range of multiple manifestations of the mafic - ultra-

\section{References}

- Ahjos T, Uski N (1992) Earthquakes in Northern Europe in 1375-1989. Tectonophysics 207(1-2): 1-23. https://doi. org/10.1016/0040-1951(92)90469-M mafic magmatism within the Kola region and, consequently, are the most weakened sections in the Earth's crust of the region. Thus, a lens-shaped belt structure of the crust was already formed in the Archaean, which along with the vertical layering acquires lateral mosaic inhomogeneity. Hence, the system of permeable zones in the basement of the Kola region formed in the Early Precambrian determined the course of development of geodynamic and mantle igneous processes in later epochs. In addition, a significant part of the seismic events of the region (especially earthquakes with a magnitude of $M=5$ and above) are concentrated where detected mobile-permeable zones of the crystalline basement are developed.

Notably, the seismicity in the Murmansk region has doubled in the last 30 years and is assumed to be capable of reaching 6 points on the MSK- 64 scale (Vinogradov et al. 2016). In addition, the powerful mining complex of the region has been generating a significant number of technogenic seismic events. As a result, the vulnerability of both civil and industrial facilities increases, even with relatively weak seismic effects. It is necessary to remember that the sustainable geological environment is a guarantee of the geoecological safety in underground nuclear power plants. The geological environment is a very mutable structure, and its detailed study shall be much expensive. The performed studies using numerical modeling and available data on geology and tectonic structure made it possible to identify the weakened zones (areas of activation) in the geological basement of the region. The obtained results allow choosing the most favorable areas for construction and conducting a special study within them. At the same time, it saves time and money, and the informative value of the results may be useful in solving a wide range of construction tasks.
- Balagansky VV (2002) Tectono-stratigraphic terrain analysis as a basis for tectonic zoning. In: Mitrofanov FP (Ed.) Geology and Mineral Resources of the Kola Peninsula (Vol. 1) - Ge- 
ology, geochronology and geodynamics. Publishing House of the Kola Science Center of the Russian Academy of Sciences, Apatity, 44-56.

- Baranov SV, Vinogradov YuA, Nikolaeva SB, Petrov SI (2011) Seismicity of Kola Peninsula according to instrumental data. In: Malovichko AA (Ed.) Modern Methods of Processing and Interpretation of Seismological Data. Materials of the Sixth International Seismological Workshop. Publishing House of the Geophysical Survey of the Russian Academy of Sciences, Obninsk, 47-51.

- Barbey P, Convert J, Moreau B, Capevila R, Hameurt J (1984) Petrogenesis and evolution of an early Proterozoic collision orogenic belts: the granulite belt of Lapland and Belomorides (Fennoscandia). Bulletin of the Geological Society of Finland 56(1-2): 164-188.

- Bayanova TB, Pozhilenko VI, Smol'kin VF, Kudryashov NM, Kaulina TV, Vetrin VR (2002) Catalogue of geochronological data for the northeastern part of the Baltic shield. Publishing House of the Kola Science Center of the Russian Academy of Sciences, Apatity, 53 pp.

- Bel'kov IV (1987) Evolution of the Earth's Crust and Endogenous Metallogenic Zonality in the Northeastern Part of the Baltic Shield. Nauka, Leningrad, 112 pp.

- Berthelsen A, Marker M (1986) Tectonics of Kola collision suture and adjacent Archean and Early Proterozoic terrains in the north-eastern region of the Baltic Shield. Tectonophysics 126(1): 31-55.

- Crouch SL, Starfield AM (1983) Boundary Element Methods in Solid Mechanics. George Allen \& Unwin, London, 322 pp.

- Filatova VT (2009) Evaluation of the strassed deformed State of the Earth's crust in the northeastern part of the Baltic Shield in the Late Archaean. Doklady Earth Sciences 424(1): 118122. https://doi.org/10.1134/S1028334X09010255

- Filatova VT (2014) Formation of Frame Tectonogens in the Northeastern Part of the Baltic Shield. Doklady Earth Sciences 455(2): 430-435. https://doi.org/10.1134/S1028334X14040047

- Kalashnik AI, Maksimov DA (2016) On Approaches to Seismic Rick Assessment and Zoning of the Kola Peninsula in Relation to the Surface linearly Extended Objects. Herald of the Kola Science Center of the RAS 16(2): 44-51.

- Kroner A, Compston W (1990) Archean tonalitic gneiss of Finish Lapland revisited: zircon ion-microprobe ages. Contributions to Mineralogy and Petrology 104(3): 348-352. https:// doi.org/10.1007/BF00321489
Lovchikov AV (2013) Review of the strongest rockbursts and mining-induced earthquakes in Russia. Journal of Mining Science 49(4): 572-575. https://doi.org/10.1134/ S1062739149040072

- Melezhik VA, Sturt BF (1994) General geology and evolutionary history of the Early Proterozoic Polmak - Pasvik - Pechenga - Imandra - Varzuga - Ust'Ponoy Greenstone Belt in the Northeastern Baltic Shield. Earth-Science Reviews 36(3-4): 205-241. https://doi.org/10.1016/0012-8252(94)90058-2

- Mel'nikov NN (2002) Seismicity in Mining. Publishing House of the Kola Science Center of the Russian Academy of Sciences, Apatity, 325 pp.

- Mints MV, Glaznev VN, Konilov AN, Kunina NM, Nikitichev AP, Raevsky AB, Sedikh YuN, Stupak VM, Fonarev VI (1996) The Early Precambrian of the Northeastern Baltic Shield: Paleogeodynamics, Crustal Structure and Evolution. Transactions of GIN RAS, vol. 503. Scientific World, Moscow, 277 pp.

- Mitrofanov FP (1996) Geological Chart of the Kola Region (Northeastern Part of the Baltic Shield) (Scale 1: 500 000). Publishing House of the Kola Science Center of the Russian Academy of Sciences, Apatity.

- Mitrofanov FP, Pozhilenko VI, Smolkin VF, Arzamastsev AA, Yevzerov VYa, Lyubtsov VV, Shipilov EV, Nikolaeva SB, Fedotov ZhA (1995) Geology of the Kola Peninsula (Baltic Shield). Publishing House of the Kola Science Center of the Russian Academy of Sciences, Apatity, 144 pp.

- Muskhelishvili NI (1966) Some of the Main Problems of the Mathematical Theory of Elasticity. Nauka, Moscow, 707 pp.

- Nikolaeva SB (2001) Paleoseismic deformation structures in the northeastern Baltic Shield and their geological and tectonic settings. Geomorfologiya 4: 66-74.

- Nikolaeva SB (2002) The epicentral areas of the paleo-earthquakes of the Kola region. In: Sharov NV (Ed.) The Deep Structure and Geodynamics of Fennoscandia and Marginal and Intraplatformtransition Zones. Materials of the Eighth International Conference. Publishing House of the Karelian Research Centre of the Russian Academy of Sciences, Petrozavodsk, 175-176.

- Nikolaeva SB (2006) Seismogenic deformations in Early Holocene sediments of the Pechenga River terrace (Kola Peninsula). Doklady Earth Sciences 406(1): 4-7. https://doi. org/10.1134/S1028334X06010028

- Nikolaeva SB, Yevzerov VYa (2018) On geodynamics of the Kola region in the later Pleistocene and Holocene: the review 
and results of the studies. Bulletin of the Voronezh State University, Geology Series 1: 5-14.

- Panasenko GD (1969) Seismic Features of the Northeastern Baltic Shield. Nauka, Leningrad, 184 pp.

- Petrov VP (1999) Early Proterozoic Metamorphism in the Baltic Shield. Publishing House of the Kola Science Center of the Russian Academy of Sciences, Apatity, 325 pp.

- Petrov VP, Belyaev OA, Voloshina ZM, Bogdanova MN, Ivliev AI (1986) Metamorphism of supracrustal complexes of the Early Precambrian age (northeastern part of the Baltic shield). Nauka, Leningrad, 272 pp.

- Radchenko AT, Balaganskii VV, Vinogradov AN, Golionko GB, Petrov VP, Pozhilenko VI, Radchenko MK (1992) Precambrian Tectonics of the Northeastern Part of the Baltic
Shield (explanatory note to the tectonic chart 1: 500 000). Nauka, St. Petersburg, 111 pp.

Sheinmann YuM (1968) Notes on the Deep Geology. Nedra, Moscow, $231 \mathrm{pp}$.

- Stepanov VV (2001) Seismic Hazard of Industrial Infrastructure. Nauka, Moscow, 100 pp.

- Vinogradov YuA, Kremenetskay EO, Asming VE, Zhirov DV (2016) Modern seismicity in mining areas in the Murmansk region. Journal of Mining Science 52(1): 46-52. https://doi. org/10.1134/S1062739116010113

- Zagorodnyi VG, Radchenko AT (1983) Tectonics of the Early Precambrian in the Kola Peninsula (State of the Investigation and Problems). Nauka, Leningrad, 96 pp. 